\title{
Theoretical and Methodological Approaches for Investigating Open Educational Practices
}

\author{
Michael Paskevicius \\ Faculty of Education, University of Victoria \\ Valerie Irvine \\ Faculty of Education, University of Victoria
}

\author{
Correspondence: \\ Michael Paskevicius \\ University of Victoria \\ Email: mpaskevi [at] uvic.ca
}

\begin{abstract}
To date, the phenomenon associated with open education in relation to teaching and learning practices remain under-theorized in the literature, which represents both a challenge and opportunity for further research (Bulfin et al., 2013; Howard \& Maton, 2011; Knox, 2013; Veletsianos, 2015). There exists an opportunity to develop new theory, as well as to connect the phenomenon to existing theory from education, learning sciences, and pedagogical research. Much of the literature has focused on case studies, strategies for implementation, and broad approaches to institutional change which do not draw upon or develop theory. A significant amount of the empirical work reviewed makes no mention of a theoretical base aside from that of openness as a conceptual framework for considering education. Further, critical studies which examine the pedagogical and educational implications of the use of open educational resources (OER) and engagement in open educational practices (OEP) are even less common (Knox, 2013). In this paper, we share the results of a literature review which investigates both methodological and theoretical approaches used in the available research on open educational practices, with the goal of engaging participants in a critical review of the theoretical and methodological approaches to further advance research in this emerging space.
\end{abstract}

Keywords: open educational practice, open pedagogy, research methods 


\section{Introduction}

In this paper, we review the methods and theories employed in empirical research on open educational practices (OEP). We conducted a literature review to identify the methods researchers have used to gather data and the theoretical constructs that have been used for researching the OEP phenomenon. We define OEP as teaching and learning practices where openness is enacted throughout all aspects of learning design, including the design of learning outcomes, the selection of teaching resources, and the planning of activities and assessment. This definition suggests that OEP involves both educators and learners with the use and creation of OER, draws attention to the potential afforded by open licenses, facilitates open peer-review, and supports participatory learner-directed projects (Paskevicius, 2017). We believe this conceptualization of OEP foregrounds new forms of teaching and learning practices and the ways in which openness offers new possibilities for action for both educators and learners.

In the present context of the COVID-19 pandemic, educators have needed to rapidly shift to facilitating remote and online learning (Bozkurt et al., 2020). No longer could educators draw upon the physical resources found in their classrooms and libraries, prompting an opportunity to explore the use of online learning materials, online collaborative tools, flexible learning outcomes, and emergent forms of assessment. Digital learning materials that can be shared online are critically needed to support each learner working from home. This presents a significant opportunity for the adoption of OER, which include legal terms for use, remix, and adaptation. Many OER can be adapted to meet the educational goal and can also be used for learner-generated creative projects. Educators may also look to OER that include a description of teaching activities and learning plans (Jhangiani et al., 2016; Kimmons, 2016; Petrides et al., 2011). Beyond the sharing of resources, OER could and should include descriptions for how they may be used, for both in-class and online activities. Some already do and, in so doing, can be collaboratively improved over time. This availability of these descriptive learning design focused OER may create opportunities for the collaborative development of learning resources and designs (Masterman \& Wild, 2011; Petrides, Jimes, Middleton-Detzner, Walling, \& Weiss, 2011).

With regards to assessment, the use of OEP has been argued to promote the formation of creative, networked, and engaging forms of student work. Assessments such as exams and term tests become challenging in a distributed learning environment, and is it worth the effort of employing "lock-down browsers" and intrusive surveillance technology to run online quizzes? Turning to OEP suggests a focus on considering what learners can create during this time, from their home, and perhaps even using OER to create artefacts that demonstrate their learning.

Online learning strategies have been cast into the spotlight during the pandemic and issues such as access to resources, supporting learner agency, and student engagement remain a prevalent challenge for many educators. Scholars have suggested that OEP present some options for supporting free access to learning materials, learner directed projects, and prospects for student engagement. Therefore, we believe, now, more than ever, it is important to understand the methods researchers are using to investigate OEP and what theoretical frameworks are being used to describe the phenomenon. 


\section{Review of Literature}

Peters and Deimann (2013) argue that openness in education has a long and diverse history. They suggest that openness is not driven solely by recent technological developments but represent a social, cultural, and economic phenomenon which have prompted universities to offer public lectures, open access universities, and flexible programming. Historically, this positioned universities as centres for accessible research and promoted public access to knowledge. More recently, openness has been broadly defined as an approach to teaching and learning which embraces social justice as a core value (Bali et al., 2020; Hodgkinson-Williams \& Trotter, 2018; Lambert, 2018). In this way, openness reflects an intentional approach to both the creation and sharing of learning resources and the design of learning experiences that addresses the needs of learners with inclusivity and equity as core values. This may take on many forms including one's broad philosophy and approach to pedagogy from the perspective of access and equity (Kimmons, 2016) including the methods in which educational content and material are sourced, created, remixed, and shared (Fischer, Hilton, Robinson, \& Wiley, 2015; Pitt, 2015; Jhangiani et al., 2016). This may also include the open sharing of pedagogical practices among educators (Petrides et al., 2011; Borthwick \& Gallagher-Brett, 2014). On the other hand, openness has been framed as way to design learning experiences, engaging learners as active producers and stakeholder in the creation of knowledge (Masterman \& Chan, 2015; Cronin, 2016; Masterman, 2016; Tur et al., 2016; Wiley, 2016) and enabling and broadening access to this knowledge into our communities (Carey et al., 2015).

Openness has a long history as a core value in higher education, and one can often see aspects of this in university mission and vision statements. Openness in education has garnered significant interest lately due to the COVID-19 pandemic; however, interest has been increasing throughout the years due to the evolving affordances offered by the internet, individuals' willingness to share and collaborate, the emergence of open copyright licenses, and the development of many freely available open publishing tools. These technological, social, legal, and financial changes have provided new ways of conceptualizing and enacting openness by supporting the sharing and collaboration of resources, sharing of teaching practices, and emerging ways of openly engaging with and creating content online (Hodgkinson-Williams \& Gray, 2009).

Open educational practices, open pedagogy, open teaching, or open practices, often used interchangeably, have been defined as "the next phase in OER development, which will see a shift from a focus on resources to a focus on OEP being a combination of open resources use and open learning architectures to transform learning" (Camilleri \& Ehlers, 2011, p. 6). Cronin (2017) defined OEP as the "collaborative practices that include the creation, use, and reuse of OER, as well as pedagogical practices employing participatory technologies and social networks for interaction, peer-learning, knowledge creation, and empowerment of learners" ( $p$. 4). These definitions suggest an expansive view of openness in teaching and learning focused on the practices enabled and supported by the open movement, either in making use of OER, engaging learners in openness, or making our professional practice more accessible. Scholars have suggested a movement towards OEP provides an impetus for innovative teaching and learning processes, resulting in new conceptualizations of the roles and practices of both educators and learners (Lane \& McAndrew, 2010; Porter, 2013; Littlejohn \& Hood, 2016). In this way, engaging with open education has been suggested as a possible catalyst for pedagogical innovation in higher education, specifically for those not classically trained in pedagogy. Increased sharing of educational practices enable educators to access one another's

Open/Technology in Education, Society, and Scholarship Association Journal: 2021, Vol. 1(2) 1-19 
pedagogical learning designs and approaches, providing greater diffusion of innovation and community formation around innovation in teaching and learning.

Several researchers have conducted literature reviews to investigate open education. For example, Cronin and MacLaren (2018) conducted a literature review to examine how the concept of OEP has evolved historically, finding expansive conceptualisations of the term in practice throughout the literature. Similarly, Koseoglu and Bozkurt (2018) reviewed literature referencing OEP, and used descriptive statistics, social network analysis, text mining, and content analysis to identify trends and patterns in the literature. Their findings suggest that many researchers use the term OEP to capture the different dimensions of open education with a focus on the processes of education, namely pedagogy. In a related study, Bozkurt, Koseoglu, and Singh (2018) find disparities in academic contributions to the literature from across the globe and recommend a greater focus on OEP, finding ways to investigate the factors that influence OER usage and engagement with OEP, and a need to extend research into openness to all levels of education. To address the latter, Blomgren and MacPherson (2018) explored the literature on OEP in K-12 learning contexts, finding limited research into the phenomenon among K-12 educators, while noting the potential for the integration of OEP in this context. As well, country-specific research has been conducted, for example Tlili, Huang, Chang, Nascimbeni, and Burgos (2019) who conducted a literature review of OER and OEP research from China. Our extension of this work includes a look at the research into OEP from a methodological and theoretical lens, to better understand how researchers are investigating the phenomenon and what theoretical frameworks are being employed in the literature.

\section{Methods}

\section{Research Question}

This literature review focuses specifically on research that investigates changes to teaching and learning practices in relation to open education. When selecting studies for the review, the focus was on those studies that conducted an empirical investigation into pedagogical changes as a result of the use of OER or changes to the design of learning in light of open education. The research question addressed was: what methods and theoretical constructs are researchers using to investigate changes to teaching and learning practices in relation to open education?

\section{Search Criteria}

The literature review draws upon studies which detail the impact of openness on teaching and learning. The Web of Science was initially used to source literature in relation to the search terms "open educational practice," "open education practice," and "open pedagogy" published from 2010 to 2020. Additional queries were conducted using the University of Victoria library to scan the ERIC, JSTOR, ProQuest, and ScienceDirect databases. Google Scholar was also used to scan for additional literature. Citation tracing methods were further used to locate research cited within the works reviewed. The corpus of literature was then narrowed to focus on empirical research specifically focused on open education in relation to learning design and pedagogy.

\section{Inclusion and Exclusion Criteria}

A total of 107 articles were identified that used these terms in the title, abstract, or article keywords. The resulting literature was then narrowed to include only empirical research that focused specifically on how open education was shifting the practice of teaching and learning, 
either through the use of OER which resulted in changes to educational practice or where OEP was being discussed as a way of engaging in new forms of teaching and learning. Several papers that looked at OEP as an institutional quality were removed, as the framing of this research explores OEP from a teaching and learning perspective. While institutions can support and foster OEP, we believe that OEP can only be enacted through the actions of educators and learners.

Studies were excluded when they were not available with an English translation or when the paper was discussing openness but not with a focus on investigating the impact on teaching and learning. The resulting corpus of works included journal papers, conference papers, PhD theses, and reports.

\section{Results}

The review resulted in a total of 65 works that detail empirical research into this phenomenon. The articles spanned from 2010 to 2020 and included a variety of publications, regions, contexts, etc. Three articles were included from 2010, four from 2011, six from 2012, four from 2013, three from 2014, five from 2015, nine from 2016, six from 2017, nine from 2018, ten from 2019, and six from 2020. Figure 1 displays the number of articles included by year of publication.

\section{Figure 1}

\section{Time Distribution of Studies}

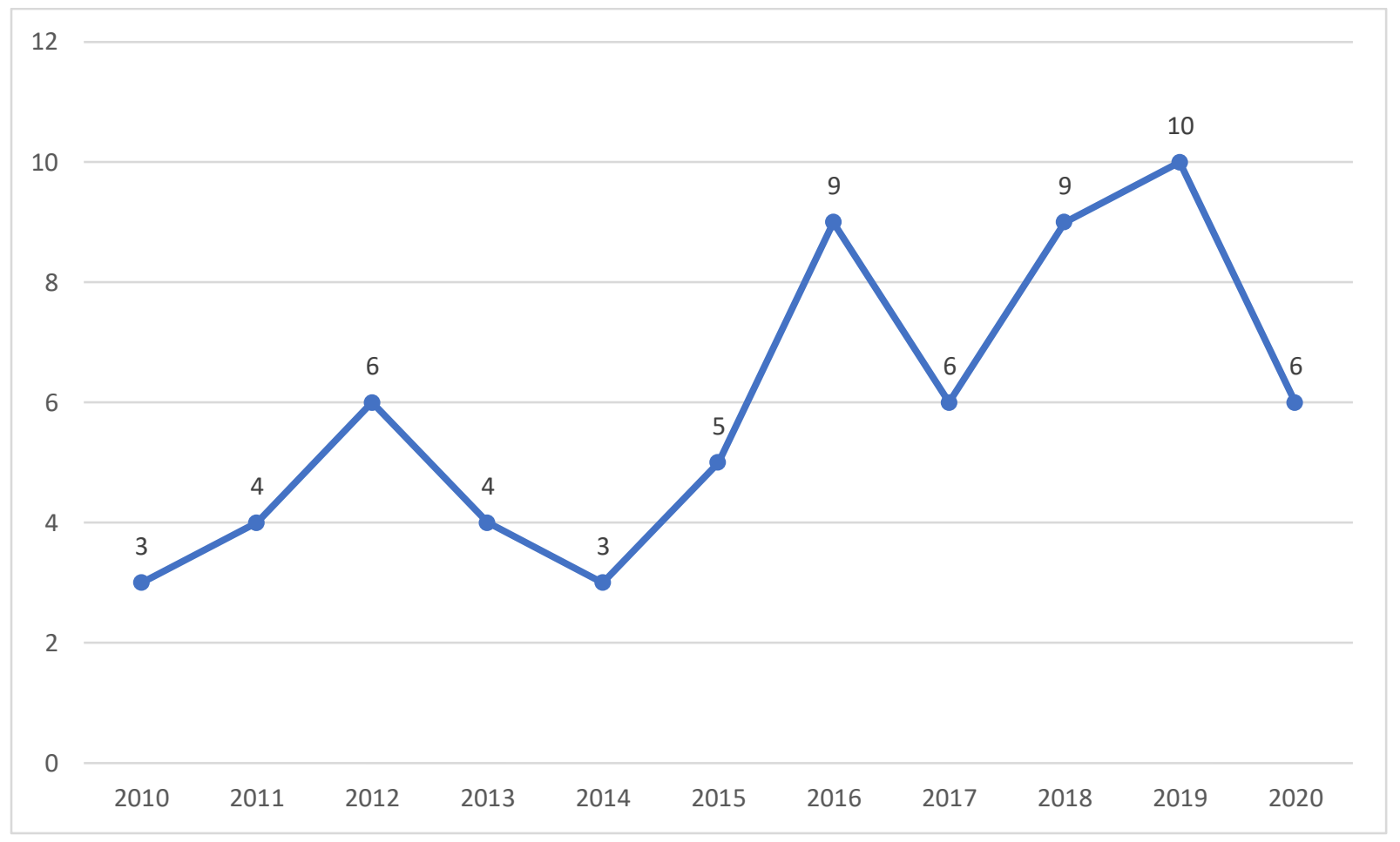

The time distribution shows an upward trend in publications on this topic, and it should be noted that it was the middle of 2020 when the search was conducted. 
The works reviewed covered a variety of educational contexts, 48 from higher education, six from K-12, and one from a workplace learning context. Several studies spanned multiple contexts or including, K-12 and higher education (four), K-12, higher education and workplace learning (two). Finally, several studies were further situated in specific context areas for example in the study of pre-service $\mathrm{K}-12$ teachers (four).

Two studies were conducted in Australia, one in Brazil, six in Canada, one in Colombia, one in India, one in Ireland, two in Italy, one in Kyrgyzstan, one in Netherlands, one in Portugal, four in South Africa, one in Spain, five in Sri Lanka, eleven in United Kingdom, one in Uruguay, and thirteen in the United States. Figure 2 displays the geographical distribution of the works reviewed. Beyond what is shown on the map, there were 11 studies that took a global perspective and were not situated within a geographical region. Additionally, there were three studies that were conducted in several countries within the European Union.

\section{Figure 2}

\section{Countrywide Distribution of Sampled Publications}

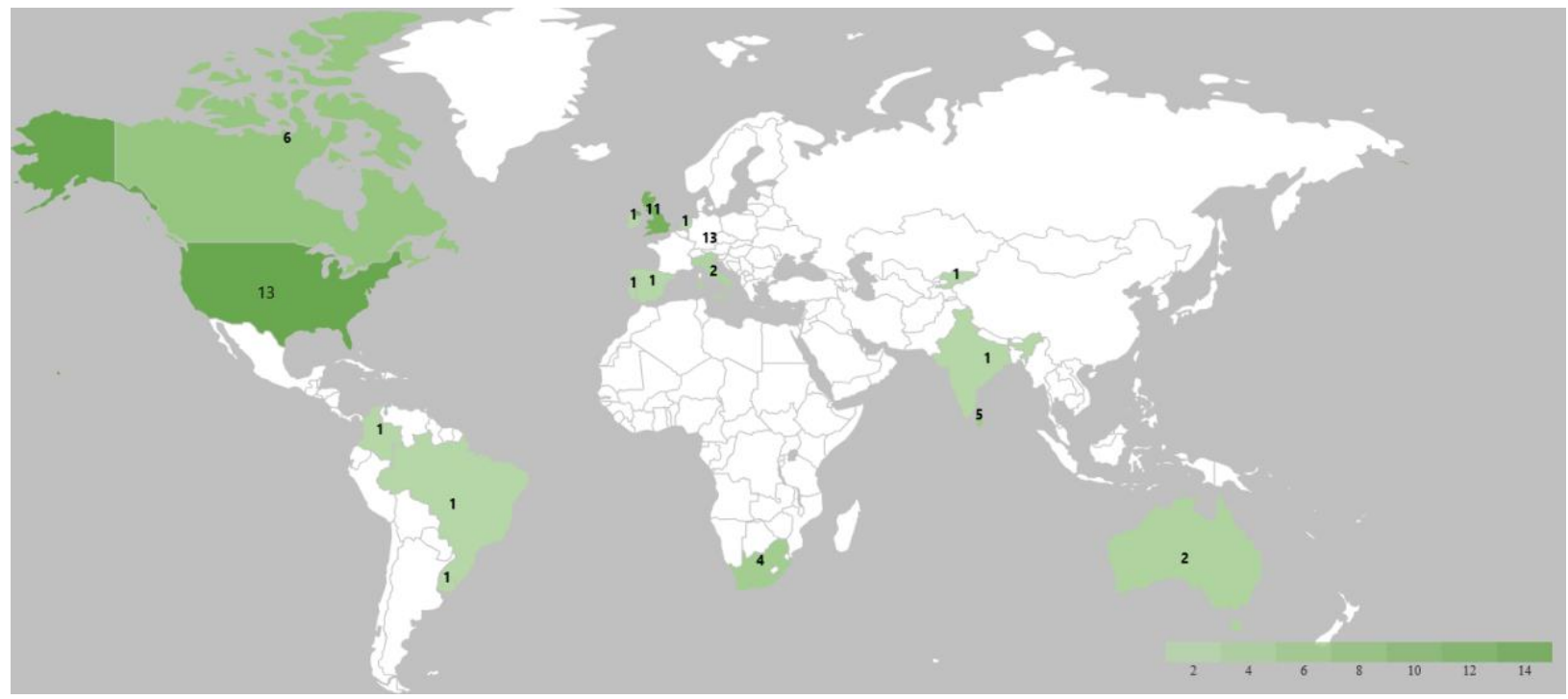

The works reviewed included one book chapter, two conference papers, 53 journal articles, seven reports, and two Ph.D. thesis. Table 1 displays the publication types, frequency, and open access policies for the sampled works.

It should be noted that several of the journals that are not open access publications do offer open access options for authors of individual articles. These journals, which refer to themselves as hybrid access, charge an open access fee to the author to make their individual work openly available. Whether an open access fee applied for each article was not checked and the open access policy indicated above is the broad policy of the journal. In total, 33 of the 52 journal articles reviewed were published in journals that maintain open access policies. 


\section{Table 1}

Publication Types of Sampled Publications and Open Access Policies

\begin{tabular}{|c|c|c|}
\hline Item type | Publication Name & \# & $\begin{array}{c}\text { Open } \\
\text { access }\end{array}$ \\
\hline \multicolumn{3}{|l|}{ Book } \\
\hline Book chapter & 1 & No \\
\hline \multicolumn{3}{|l|}{ Conference paper } \\
\hline OER12 and OpenCourseWare Consortium & 1 & Yes \\
\hline OpenED Proceedings & 1 & Yes \\
\hline \multicolumn{3}{|l|}{ Journal } \\
\hline Asian Association of Open Universities Journal & 1 & Yes \\
\hline Brain & 1 & Yes \\
\hline British Journal of Educational Technology & 1 & No \\
\hline Canadian Journal for the Scholarship of Teaching and Learning & 1 & Yes \\
\hline Computer Assisted Language Learning & 1 & No \\
\hline Computers in Human Behavior & 1 & No \\
\hline Distance Education & 9 & No \\
\hline Educational Technology Research and Development & 1 & No \\
\hline Educause & 1 & Yes \\
\hline E-Learning and Digital Media & 1 & No \\
\hline Higher Education & 1 & No \\
\hline International Journal of Emerging Technologies in Learning (iJET) & 1 & Yes \\
\hline Journal of Computing in Higher Education & 1 & Yes \\
\hline Journal of E-Learning and Knowledge Society & 2 & Yes \\
\hline Journal of Interactive Media in Education & 5 & Yes \\
\hline Latin-American Learning Technologies Journal & 1 & No \\
\hline Open Learning & 1 & No \\
\hline Open Praxis & 12 & Yes \\
\hline Research in Learning Technology & 1 & Yes \\
\hline Sustainability & 1 & Yes \\
\hline Teachers College Record & 1 & No \\
\hline Teaching in Higher Education & 1 & No \\
\hline The Electronic Journal of e-Learning & 1 & Yes \\
\hline International Review of Research in Open and Distributed Learning & 6 & Yes \\
\hline \multicolumn{3}{|l|}{ Report } \\
\hline Report & 7 & Yes \\
\hline \multicolumn{3}{|l|}{ Thesis } \\
\hline Doctoral Dissertation & 2 & Yes \\
\hline
\end{tabular}


Each article was assigned a broad category based on what was being investigated. Of the studies reviewed: 15 studies focused on the factors that influence usage and uptake of OEP; 37 focused on the impact OEP was making on pedagogical practices; and 13 focused on the impact OEP was having on learners.

\section{Theoretical Approaches to Investigating OEP}

It has been argued that the phenomenon associated with open education remain undertheorized in the literature, which represents both a challenge and opportunity for further research (Knox, 2013; Veletsianos, 2015). A great deal of the literature has focused on case studies, strategies for implementation, and broad approaches to institutional change that do not draw upon or develop theory. A significant amount of the empirical work reviewed makes no explicit mention of a theoretical base. Further, critical studies which examine the pedagogical and educational implications of the use of OER and engagement in OEP are even less common (Knox, 2013).

In this review, we found a total of 33 different theories or combinations of theories applied in the literature across the 65 works reviewed. Several of the papers made little explicit mention of an established educational theory. These were coded as applying openness as a theory, either in developing new ways to frame the phenomena or building on recently proposed theory discussed below. Where theory was applied explicitly, the most common ones include activity theory, constructivism, social justice theory, and scenario-based approaches to learning. Several other well-known theories have been applied and are listed in Table 2. Each piece of the reviewed literature is represented once below. The table displays the theory referenced in the work or the combination of theory referenced together. The table is not intended to show a hierarchical relationship between theories. It rather clusters theory that has been used in combination with others on the left side, and shows additional theories applied in each study on the column to the right. It should be noted that, in some cases, the theory might have only been referenced as a heuristic for the research and not necessary applied systematically throughout the study.

Of those studies that did not explicitly reference an established theoretical framework, several new theories emerged related specifically to open education. Theories that appear to be developing in the space of open education research include Big OER vs. Little OER (Weller, 2012), a conceptual framework of open educational practices (Masterman \& Chan, 2015), the OER engagement ladder (Masterman \& Wild, 2011), and the Open Educators' Factory (OEF) framework (Nascimbeni et al., 2018; Nascimbeni \& Burgos, 2019). Beyond these more explicitly defined theories, several authors have situated their work in the idea that OEP enhances access to education while others have framed this from a cost saving perspective, both equating to greater access to learners. Others have argued that OEP provides a means to developing open culture ecologies that include digital and copyright literacies. The largest implied theory that emerged from the literature was that of openness stimulating pedagogical change. This emerged based on the new possibilities available in teaching and learning because of the availability of open resources, open publishing platforms, new ways of collaborating openly, and the possibility for both educators and learners to create knowledge to engage broader audiences. These theories appear to be in the early stages of development and do not cite a single source in their use, although resources such as the 2030 Agenda for Sustainable Development is often referenced as a founding document (UN General Assembly, 2015). 


\section{Table 2}

Theories Applied in the OEP Literature

\begin{tabular}{|c|c|c|c|}
\hline $\begin{array}{l}\text { Theory } \\
\text { Identified in } \\
\text { the Literature }\end{array}$ & $\begin{array}{l}\text { Additional theory } \\
\text { (if identified) }\end{array}$ & Additional theory (if identified) & Count \\
\hline \multirow[t]{5}{*}{ Activity theory } & \multicolumn{2}{|l|}{ Activity theory alone } & 4 \\
\hline & \multicolumn{2}{|l|}{+ Affordances } & 1 \\
\hline & \multicolumn{2}{|c|}{ + Self-regulated learning } & 1 \\
\hline & \multicolumn{2}{|c|}{ + Social realism } & 1 \\
\hline & \multicolumn{2}{|c|}{+ Social inclusion and agency } & 1 \\
\hline \multicolumn{3}{|c|}{ Boyer's multidimensional model } & 1 \\
\hline \multicolumn{3}{|c|}{ Communities of practice } & 1 \\
\hline \multirow{2}{*}{$\begin{array}{l}\text { Constructivist } \\
\text { pedagogy }\end{array}$} & \multicolumn{2}{|c|}{ Constructivist pedagogy alone } & 1 \\
\hline & \multicolumn{2}{|c|}{ + Networked pedagogy } & 1 \\
\hline \multicolumn{3}{|c|}{ Content repository drop-off } & 1 \\
\hline \multicolumn{3}{|c|}{ Kleine's choice framework / active citizenship framework } & 1 \\
\hline \multicolumn{3}{|c|}{ Knowledge sharing and social exchange theory } & 1 \\
\hline \multicolumn{3}{|c|}{ Learning design theory } & 1 \\
\hline \multicolumn{3}{|c|}{ Learning through participation and knowledge creation } & 1 \\
\hline \multirow{13}{*}{$\begin{array}{l}\text { Openness as a } \\
\text { theory }\end{array}$} & \multicolumn{2}{|c|}{ Big OER versus Little OER } & 1 \\
\hline & \multicolumn{2}{|c|}{ Conceptual framework of open educational practices } & 1 \\
\hline & \multicolumn{2}{|c|}{ Enhancing access to education } & 4 \\
\hline & \multicolumn{2}{|c|}{$\begin{array}{l}\text { Literacy and copyrights education as epistemology / Open } \\
\text { Culture Ecologies }\end{array}$} & 5 \\
\hline & \multirow{2}{*}{$\begin{array}{l}\text { OER engagement } \\
\text { ladder }\end{array}$} & OER engagement ladder alone & 1 \\
\hline & & + Openness as pedagogical change agent & 1 \\
\hline & \multicolumn{2}{|c|}{ Open educators' factory (OEF) framework } & 2 \\
\hline & \multicolumn{2}{|c|}{ Openness as a cost saver } & 2 \\
\hline & \multirow{5}{*}{$\begin{array}{l}\text { Openness as } \\
\text { pedagogical } \\
\text { change agent }\end{array}$} & $\begin{array}{l}\text { Openness as pedagogical change agent } \\
\text { alone }\end{array}$ & 16 \\
\hline & & $\begin{array}{l}\text { + Computer-supported collaborative } \\
\text { learning }\end{array}$ & 1 \\
\hline & & + Institutional/structural factors & 4 \\
\hline & & + Learner agency & 1 \\
\hline & & + Learner agency & 1 \\
\hline \multicolumn{3}{|c|}{ Personalised and social learning } & 1 \\
\hline \multicolumn{3}{|c|}{ Scenario-based approach to learning } & 2 \\
\hline \multicolumn{3}{|c|}{ School change and reform } & 1 \\
\hline \multicolumn{3}{|c|}{ Social justice theory } & 2 \\
\hline \multicolumn{3}{|c|}{ Sociocultural and social realist theories } & 1 \\
\hline Teacher motiva & on and self-efficacy & & 1 \\
\hline
\end{tabular}




\section{Methodological Approaches to Investigating OEP}

For researchers interested in the ways in which openness are impacting teaching and learning practices, it has been suggested that "openness is the enemy of knowability" (Beetham, 2011, p. 7). This is due to the open, flexible, and unstandardized ways in which access and usage of OER occurs (Harley, 2008; Pulker \& Calvi, 2013; Weller et al., 2015). Researching the impact of openness on educational practices and outcomes represents an even greater challenge, as issues related to data protection combined with the nebulous nature of OER usage create a challenging landscape for conducting research (Weller et al., 2015). Consequently, a number of scholars have suggested more empirical research into the phenomenon is needed (Beetham et al., 2012; Borthwick \& Gallagher-Brett, 2014; Camilleri et al., 2014; Pitt, 2015; Littlejohn \& Hood, 2016).

Researchers have taken several different approaches to exploring the impact of OER on teaching and learning practices. Quantitative metrics such as web analytics which track user access to resources have been used to determine the impact and usage of OER resources and repositories. These metrics are often combined with other data sources such as document analysis (Rodgers, 2011), surveys (MIT, 2011), or in combination with qualitative methods (Petrides, Nguyen, Kargliani, \& Jimes, 2008; de los Arcos, Farrow, Perryman, Pitt, \& Weller, 2014). Analytics which display anonymous access to resources alone does not reveal much about the extent of that access on teaching and learning processes. Leslie (2010) sought to develop ways in which individual resources could be tracked, thereby revealing their evolution and sites of reuse. Again, the challenges to gaining accurate and usable reuse data are inherent in the freedoms granted through OER. OER may be taken offline, format shifted, edited, or fragmented making persistent tracking problematic.

Conversely, individuals engaging with OEP are often quite willing to connect, discuss, and share their practice. This is evident from the active social media activity and numerous annual conferences organized around open education. Several researchers have attempted to investigate the openly accessible online artefacts and discourses related to open education found on the web. Examples include critical discourse analysis studies on OER project websites (Dos Santos, 2008); discourse analysis of popular media coverage of open education (Bulfin et al., 2014); analysis of conference proceedings for the annual OpenEd conference (Kernohan, 2015); content analysis of research articles specifically relating to OER (Weller, 2016); and content analysis of Twitter activity generated about open education (Baker III, 2014; Paskevicius et al., 2018).

Among the studies reviewed, we found a variety of methods used for investigating OEP related to teaching and learning. In total, 21 studies used content analysis as method of inquiry, nine using content analysis alone, one combining content analysis with a focus group, two combining content analysis with interviews, one using content analysis in combination with network analysis, one using content analysis, focus groups, and interviews, four combining content analysis, focus groups, interviews, and surveys, and three using content analysis, interviews, and surveys. Five studies used focus groups, two of which combined focus groups with interviews and three using focus groups and surveys. Interviews were used in 23 of the studies, 12 of these used interviews alone and 11 combined interviews and surveys. Surveys were used in 13 of the studies, 12 of these used surveys alone and one combined surveys and focus groups. Finally, two studies used a quasi-experimental research design and one used a learning design analysis approach. 
Surveys have been used often to gather feedback on the attitudes and beliefs of educators engaging with OEP (Andrade et al., 2011; Van Acker et al., 2014; Jhangiani et al., 2016; Tur et al., 2016). Surveys are excellent tools for gathering sentiments and trends, allowing the researcher to access a large population of people. However, there are limitations when using a survey if the goal is developing a detailed understanding of a phenomenon (Creswell, 2013). While open-ended questions may be used as part of a survey there is no way to ensure participants provide an answer or probe deeper if they do. Jhangiani et al. (2016) noted a low response rate for open-ended questions in their survey, while Andrade et al. (2011) recommend a deeper and in-depth analysis of qualitative data in order to better understand the perceptions and interpretations around OEP.

Some researchers used content analysis in addition to other methods to deepen their inquiry into OEP. Content analysis was conducted based on open course material, an educator's written or recorded reflections of engaging with OEP, the analysis of student works created, or reviewing learning design documents and descriptions. The use of content analysis as a method was often combined with other qualitative approaches. Content analysis of OEP artefacts represent important contributions to the body of research on open education and employ methods which are in effect made possible by data sources which have been created as a result of educators and researchers engaging in more open practices (King et al., 2016).

Many researchers have adopted qualitative methodologies while investigating the experience of practitioners engaging in OEP. A qualitative approach is particularly useful when investigating changes to educator and learner's practice and the lived experiences enacting that change (Masterman \& Wild, 2011). Interviews are popular methods for gathering qualitative data which seek to explore an educator's perceptions of OEP. Several researchers have conducted interviews with goals of: understanding what factors influence engagement with OEP (Alevizou, 2012; Wild, 2012; Beaven, 2013; Masterman \& Chan, 2015; Masterman, 2016); determining the impact of OEP on pedagogy (Porter, 2013; Littlejohn \& McGill, 2016); and the impact of OEP on learners (Hodgkinson-Williams \& Paskevicius, 2012). Interviews are often conducted by asking open-ended questions which allow for an in-depth and unstructured discussion with participants. Interviews should enable participants "to discuss their interpretations of the world in which they live, and to express how they regard situations from their own point of view" (Cohen et al., 2007, p. 349).

Using a combination of surveys and interviews is also a popular approach in the literature. This mixed-methods approach can be used to invite interview participation after the completion of a survey to verify emergent ideas and develop working theories (Creswell, 2012). For example, surveys may be used to generate an initial dataset which can then be probed and expanded upon further during interviews. Noting that all methods have their strengths and weaknesses, Gray (2014) suggests considering mixed methods to balance out weaknesses in any single data collection process through methodological triangulation.

Computer-mediated qualitative data collection techniques are becoming increasingly acceptable considering technological developments (Ruhleder, 2000; Stewart \& Williams, 2005; Salmons, 2010; Nehls et al., 2015). Interviews may be conducted online through synchronous communication tools allowing participant to see and hear one another, share their screens, and exchange text and other multimedia resources. This emergent method of conducting interviews has been taken up by researchers of OEP (Lane, 2010; Beaven, 2013). There are several advantages and disadvantages to conducting interviews via this medium. For both interviewee

Open/Technology in Education, Society, and Scholarship Association Journal: 2021, Vol. 1(2) 1-19 
and interviewer, this method is convenient and saves potential travel costs to the research site thereby creating greater access to remote interviewees (Salmons, 2011). Another advantage of conducting synchronous online interviews is the ability for both participants to see each other as well as share their computer screen, allowing them to demonstrate or share something visual. This may be useful in the case of reviewing artefacts which interviewees would like to show as part of the interview, which may add richness to the data and allow for content analysis (Beaven, 2013). Recording of the audio, video, and artefacts captured through screen-sharing can be done quite simply and unobtrusively in these environments either through built-in tools or screen recording software. Conversely, facilitating and participating in online synchronous interviews may be new to some participants which could negatively impact the interview process (Nehls et al., 2015). Technical challenges also present potential disadvantages and may impact the interview. As interviewee and interviewer do not share the same space, there is a further potential for distraction, or miscommunication either through body language or verbal communication. Despite these challenges, and certainly accelerated through increase in synchronous online meetings due to COVID-19, this method represents a sensible approach to conduct research into OEP that allows the researcher to cast a more geographically dispersed and potential more diverse sample of users.

\section{Discussion}

Cohen et al. (2007) have argued that while areas of research such as the natural sciences, are characterized by a high degree of sophistication; theory around open education remains in the early stages of formulation. While that idea seemed to be confirmed through this literature review, there appears to be a new rationale emerging for inquiry into OEP. This rationale was often detailed in the literature review section of papers providing context for the research. In the absence of explicit theory referenced among many of the studies reviewed, the notion of openness as a change agent often surfaced. Openness as a motivator for change was associated with several different outcomes: those based around the cost of education, access to educational experiences, openness as a source of pedagogical innovation, or providing exceptional learning experiences for our students. These ideas could be more explicitly linked back to theories of change management, technological affordances, theory that explores structure and agency, innovation theory, or those more established educational theories such as social constructivism, the zone of proximal development, or experiential learning. Even more so, there is an opportunity to ground the phenomenon of OEP to more modern educational theory such as that of connectivism or online communities of practice/inquiry. We believe it important that theoretical contributions involving OEP acknowledge, are situated within, or develop established educational theory.

There is a significant opportunity to contribute to the body of research on OEP and develop theory that would strengthen arguments across the research and open opportunities for further research. As learning designs become more openly accessible, there may be an opportunity to examine learning experiences through trace activity data. As many of the artefacts created through OEP are largely openly accessible, emergent practices such as the examination of web analytics and content analysis of online artefacts and social network analyses of online discussion are made possible. This gives rise to the opportunity for examining OEP from a student perspective, to investigate how learners engage with openness, and how this impacts learning and development. 
Data collected from individuals using surveys provides an initial source of data to design further qualitative research using more in-depth interviews or focus groups. The potential for combining data from a variety of sources, as well as using novel approaches for collecting qualitative data provide an exciting landscape for research. New contributions to open data and the sharing of research, research instruments, and datasets more broadly through open access journals presents an interesting opportunity to triangulate results.

By itself, OEP appears to be about change and new forms of teaching and learning practices. Could we as researchers find a way to leverage existing theories of change to better describe and unpack these phenomena? If openness stimulates pedagogical change, what new issues and considerations arise over time as educators change their practice and learners engage in new ways? Researchers may consider being more explicit about acknowledging existing educational theory and developing theory to explain open education phenomenon. As Kalir (2020) articulated in a recent paper, one approach is a combination of developing theory to explain the complexities inherent in OEP combined with an established theoretical base appropriate for the unit of analysis.

\section{Limitations}

Not all of the scholarship in this area may have been captured through the literature review due to limitations around the use of consistent keywords for this phenomenon. As well, this study did not include a review of the grey literature such as scholarly blogs where stories of shared practice around OEP are available. There are some significant synergies in the literature between the concepts of OEP and "networked learning" or education designs which build upon "web 2.0" principles and this additional literature was not included in this review. The primary difference between the practices associated with networked learning and OEP is the explicit inclusion of open education literacies and the action of making works openly available in the latter. Networked learning practices introduce several key literacies to learners for working and collaborating on the web. OEP extends those literacies to include the practices of open collaborative knowledge formation and the sharing of works using appropriate copyright models such as Creative Commons and the public domain to support greater access to knowledge (Dohn, 2009). Further research is needed to determine what additional value OEP might add beyond that of networked learning designs and it would be interesting to explore if networked learning has evolved into OEP or remains a field on its own. Finally, only articles written in English were considered as part of this study.

\section{Conclusion}

Several researchers have suggested further research is needed to understand the pedagogical implications of OEP (Beetham et al., 2012; Knox, 2013; Camilleri et al., 2014; Pitt, 2015; Littlejohn \& Hood, 2016). The OER movement has been successful in creating awareness of the potential for the creation, sharing, and adoption of educational artefacts under open licenses. In defining this movement merely in terms of OER and their usage, rather than focusing on the practices and knowledge associated with OER, insights may be lost (Hope, 2015). Our intention is that this paper prompts research design considerations for future scholars interested in investigating the phenomena around open education. 


\section{Author's Contributions}

MP conducted the literature review, designed the study, analyzed the results, and prepared the findings. VI provided guidance, review, and feedback throughout all aspects of the study. Both authors read and approved the final manuscript.

\section{Open Researcher and Contributor Identifier (ORCID)}

Michael Paskevicius (iD https://orcid.org/0000-0001-7391-0783

Valerie Irvine (iD https://orcid.org/0000-0002-8067-1300

\section{Ethics Statement}

Please identify whether ethical approval was obtained for the work described in this article. If not, please identify whether a waiver was received or if an ethics review was not applicable. Please provide the assigned editor with evidence of a waiver, confirmation from a review board that it was not required, or contact the editor to discuss this further.

\section{Conflict of Interest}

The authors do not declare any conflict of interest.

\section{Data Availability Statement}

The data for this study resides with the correspondence author. Access to the data is possible through an email request.

\section{References}

Alevizou, P. (2012, March). Open to interpretation?: Productive frameworks for understanding audience engagement with OER. Cambridge 2012: Innovation and Impact - Openly Collaborating to Enhance Education, a joint meeting of OER12 and OpenCourseWare Consortium Global 2012, Cambridge, UK.

Andrade, A., Ehlers, U.-D., Caine, A., Carneiro, R., Conole, G., Kairamo, A.-K., Tapio Koskinen, Thomas Kretschmer, Nick Moe-Pryce, Paul Mundin, Judite Nozes, Rolf Reinhardt, Thomas Richter, Gonçalo Silva, \& Carl Holmberg. (2011). Beyond OER: Shifting focus to open educational practices. Open Educational Quality Initiative.

Baker III, F. W. (2014). Open dialogue: A content analysis of the \#openeducation twitter hashtag. Association of Educational Communication Technology Annual Conference, Jacksonville, FL. http://www.fredwbaker.com/wp-content/uploads/2015/02/Baker-Twitteropeneducation-AECT-2014.pdf

Bali, M., Cronin, C., \& Jhangiani, R. S. (2020). Framing open educational practices from a social justice perspective. Journal of Interactive Media in Education, 1, UNSP 10. https://doi.org/10/ggzfiz

Beaven, T. (2013). Use and reuse of OER: Professional conversations with language teachers. Journal of E-Learning and Knowledge Society, 9(1). http://www.jelks.org/ojs/index.php/Je-LKS EN/article/view/802

Beetham, H. (2011). Understanding the role of OERs in open educational practices [Education]. http://www.slideshare.net/loumcgill/understanding-the-role-of-oers-in-open-educationalpractices 
Beetham, H., Falconer, I., McGill, L., \& Littlejohn, A. (2012). Open Practices Briefing Paper. Joint Information Systems Committee (JISC). https://oersynth.pbworks.com/w/page/51668352/OpenPracticesBriefing

Blomgren, C., \& MacPherson, I. (2018). Scoping the nascent: An analysis of K-12 OER research 2012-2017. Open Praxis, 10(4), 359. https://openpraxis.org/articles/10.5944/openpraxis.10.4.905/

Borthwick, K., \& Gallagher-Brett, A. (2014). 'Inspiration, ideas, encouragement': Teacher development and improved use of technology in language teaching through open educational practice. Computer Assisted Language Learning, 27(2), 163-183. https://doi.org/10.1080/09588221.2013.818560

Bozkurt, A., Jung, I., Xiao, J., Vladimirschi, V., Schuwer, R., Egorov, G., Lambert, S., Al-Freih, M., Pete, J., Don Olcott, J., Rodes, V., Aranciaga, I., Bali, M., Alvarez, A. J., Roberts, J., Pazurek, A., Raffaghelli, J. E., Panagiotou, N., Coëtlogon, P. de, ... Paskevicius, M. (2020). A global outlook to the interruption of education due to COVID-19 pandemic: Navigating in a time of uncertainty and crisis. Asian Journal of Distance Education, 15(1), $1-126$.

Bozkurt, A., Koseoglu, S., \& Singh, L. (2018). An analysis of peer reviewed publications on openness in education in half a century: Trends and patterns in the open hemisphere. Australasian Journal of Educational Technology, 0(0). https://doi.org/10.14742/ajet.4252

Bulfin, S., Henderson, M., \& Johnson, N. (2013). Examining the use of theory within educational technology and media research. Learning, Media and Technology, 38(3), 337-344. https://doi.org/10.1080/17439884.2013.790315

Bulfin, S., Pangrazio, L., \& Selwyn, N. (2014). Making 'MOOCs': The construction of a new digital higher education within news media discourse. The International Review of Research in Open and Distributed Learning, 15(5). https://doi.org/10.19173/irrodl.v15i5.1856

Camilleri, A. F., \& Ehlers, U.-D. (2011). Mainstreaming open educational practice: Recommendations for policy. European Foundation for Quality in E-Learning: The OPAL Consortium. http://efquel.org/wp-content/uploads/2012/03/Policy Support OEP.pdf

Camilleri, A. F., Ehlers, U.-D., \& Pawlowski, J. (2014). State of the art review of quality issues related to open educational resources (OER). European Commission Institute for Prospective Technological Studies.

Carey, T., Davis, A., Ferreras, S., \& Porter, D. (2015). Using open educational practices to support institutional strategic excellence in teaching, learning \& scholarship. Open Praxis, 7(2). https://openpraxis.org/articles/abstract/10.5944/openpraxis.7.2.201/

Cohen, L., Manion, L., \& Morrison, K. (2007). Research methods in education (6th ed). Routledge.

Creswell, J. W. (2012). Educational research: Planning, conducting, and evaluating quantitative and qualitative research (4th ed). Pearson.

Creswell, J. W. (2013). Qualitative inquiry and research design: Choosing among five approaches (3rd ed). SAGE Publications.

Cronin, C. (2016). Open, networked and connected learning: Bridging the formal/informal learning divide in higher education. Proceedings of the 10th International Conference on Networked Learning. http://www.networkedlearningconference.org.uk/abstracts/pdf/S3 Paper2.pdf 
Cronin, C. (2017). Openness and praxis: Exploring the use of open educational practices in higher education. International Review of Research in Open and Distributed Learning, 18(5), 15-34. https://doi.org/10.19173/irrodl.v18i5.3096

Cronin, C., \& MacLaren, I. (2018). Conceptualising OEP: A review of theoretical and empirical literature in open educational practices. Open Praxis, 10(2), 127-143. https://openpraxis.org/articles/10.5944/openpraxis.10.2.825/

De Los Arcos, B., Farrow, R., Perryman, L.-A., Pitt, R., \& Weller, M. (2014). OER evidence report 2013-2014. http://oro.open.ac.uk/id/eprint/41866

Dohn, N. B. (2009). Web 2.0: Inherent tensions and evident challenges for education. International Journal of Computer-Supported Collaborative Learning, 4(3), 343-363. https://doi.org/10.1007/s11412-009-9066-8

Dos Santos, A. I. (2008). The discourses of OERs: How flat is this world? Journal of Interactive Media in Education, 2008(1), 11. https://doi.org/10.5334/2008-11

Fischer, L., Hilton, J., Robinson, T. J., \& Wiley, D. A. (2015). A multi-institutional study of the impact of open textbook adoption on the learning outcomes of post-secondary students. Journal of Computing in Higher Education, 27(3), 159-172. https://doi.org/10.1007/s12528-015-9101-x

Gray, D. E. (2014). Doing research in the real world (3rd ed). SAGE.

Harley, D. (2008). Why understanding the use and users of open education matters. In M. S. V. Kumar, T. liyoshi, \& M. S. V. Kumar (Eds.), Opening up Education: The Collective Advancement of Education Through Open Technology, Open Content, and Open Knowledge (pp. 197-211). MIT Press.

Hodgkinson-Williams, C., \& Gray, E. (2009). Degrees of openness: The emergence of open educational resources at the University of Cape Town. International Journal of Education and Development Using ICT, 5(5), 101-116.

Hodgkinson-Williams, C., \& Paskevicius, M. (2012). The role of postgraduate students in coauthoring open educational resources to promote social inclusion: A case study at the University of Cape Town. Distance Education, 33(2), 253-269. https://doi.org/10.1080/01587919.2012.692052

Hodgkinson-Williams, C., \& Trotter, H. (2018). A social justice framework for understanding open educational resources and practices in the global south. Journal of Learning for Development - JL4D, 5(3). http://jil4d.org/index.php/ejl4d/article/view/312

Hope, A. (2015). Foucault's toolbox: Critical insights for education and technology researchers. Learning, Media and Technology, 40(4), 536-549. https://doi.org/10.1080/17439884.2014.953546

Howard, S., \& Maton, K. (2011). Theorising knowledge practices: A missing piece of the educational technology puzzle. Research in Learning Technology, 19(3), 191-206. https://doi.org/10.1080/21567069.2011.624170

Jhangiani, R., Pitt, R., Hendricks, C., Key, J., \& Lalonde, C. (2016). Exploring faculty use of open educational resources at British Columbia post-secondary institutions. https://open.bccampus.ca/files/2016/04/BCFacultyUseOfOER final.pdf

Kalir, J. H. (2020). Social annotation enabling collaboration for open learning. Distance Education, 41(2), 245-260. https://doi.org/10/ggzfj4

Kernohan, D. (2015, November 19). "Keep the Fire" - Notes on my \#opened15 presentation. Followers of the Apocalypse. http://followersoftheapocalyp.se/keep-the-fire-notes-on-myopened15-presentation/ 
Kimmons, R. (2016). Expansive openness in teacher practice. Teachers College Record, Volume 118(Number 9), 1-34.

King, T. W., Hodgkinson-Williams, C., Willmers, M., \& Walji, S. (2016). Dimensions of open research: Critical reflections on openness in the ROER4D project. Open Praxis, 8(2), 8191. https://openpraxis.org/articles/abstract/10.5944/openpraxis.8.2.285/

Knox, J. (2013). Five critiques of the open educational resources movement. Teaching in Higher Education, 18(8), 821-832. https://doi.org/10.1080/13562517.2013.774354

Koseoglu, S., \& Bozkurt, A. (2018). An exploratory literature review on open educational practices. Distance Education, 39(4), 441-461. https://doi.org/10/gf5f7k

Lambert, S. R. (2018). Changing our (Dis)Course: A distinctive social justice aligned definition of open education. Journal of Learning for Development - JL4D, 5(3). https://ji4d.org/index.php/ej|4d/article/view/290

Lane, A. (2010). Designing for innovation around OER. Journal of Interactive Media in Education, 2010, http://jime.open.ac.uk/jime/article/view/2010-2. https://doi.org/10.5334/2010-2

Lane, A., \& McAndrew, P. (2010). Are open educational resources systematic or systemic change agents for teaching practice? British Journal of Educational Technology, 41(6), 952-962. https://doi.org/10.1111/j.1467-8535.2010.01119.x

Leslie, S. (2010, July 19). Tracking downloadable OER content. Edtechpost. http://edtechpost.wikispaces.com/OLNet+-+Draft+Paper

Littlejohn, A., \& Hood, N. (2016). How educators build knowledge and expand their practice: The case of open education resources. British Journal of Educational Technology, 48(2), 499510. https://doi.org/10.1111/bjet.12438

Littlejohn, A., \& McGill, L. (2016). Ecologies of open resources and pedagogies of abundance. In B. Gros, Kinshuk, \& M. Maina (Eds.), The Future of Ubiquitous Learning: Learning Designs for Emerging Pedagogies (pp. 115-130). Springer Berlin Heidelberg. http://dx.doi.org/10.1007/978-3-662-47724-3 7

Masterman, E. (2016). Bringing open educational practice to a research-intensive university: Prospects and challenges. Electronic Journal of E-Learning, 14(1).

Masterman, E., \& Chan, J. (2015). Openness in Teaching and Learning: An Exploration of Principles and Practices at the University of Oxford [Research Report]. Academic IT group, IT Services, University of Oxford. https://weblearn.ox.ac.uk/x/nNvkjt

Masterman, E., \& Wild, J. (2011). JISC open educational resources programme: Phase 2 OER impact study [Research report]. University of Oxford.

https://weblearn.ox.ac.uk/access/content/group/ca5599e6-fd26-4203-b416f1b96068d1cf/Research\%20Project\%20Reports/OER\%20Projects\%202011 2014/JISC\%200ER\%20Impact\%20Study\%20Research\%20Report\%20v1-0.pdf

MIT. (2011). 2011 Program evaluation findings summary. MITOpenCourseWare. https://ocw.mit.edu/about/site-statistics/11 Eval Summary 112311 MITOCW.pdf

Nascimbeni, F., \& Burgos, D. (2019). Unveiling the relationship between the use of open educational resources and the adoption of open teaching practices in higher education. Sustainability, 11(20), 5637. https://doi.org/10/ggkb4s

Nascimbeni, F., Burgos, D., Campbell, L. M., \& Tabacco, A. (2018). Institutional mapping of open educational practices beyond use of Open Educational Resources. Distance Education, 39(4), 511-527. https://doi.org/10/ggzfk5 
Nehls, K., Smith, B. D., \& Schneider, H. A. (2015). Video-conferencing interviews in qualitative research. In S. Hai-Jew (Ed.), Enhancing Qualitative and Mixed Methods Research with Technology (pp. 140-157). Business Science Reference an imprint of IGI Global.

Paskevicius, M. (2017). Conceptualizing open educational practices through the lens of constructive alignment. Open Praxis, 9(2), 125. https://openpraxis.org/articles/10.5944/openpraxis.9.2.519/

Paskevicius, M., Veletsianos, G., \& Kimmons, R. (2018). An analysis of how the twitter discourse surrounding open education unfolded from 2009 to 2016. The International Review of Research in Open and Distributed Learning, 19(1). http://dx.doi.org/10.19173/irrodl.v19i1.3267

Peter, S., \& Deimann, M. (2013). On the role of openness in education: A historical reconstruction. Open Praxis, 5(1), 7-14. https://openpraxis.org/articles/abstract/10.5944/openpraxis.5.1.23/

Petrides, L., Jimes, C., Middleton-Detzner, C., Walling, J., \& Weiss, S. (2011). Open textbook adoption and use: Implications for teachers and learners. Open Learning, 26(1), 39-49. https://doi.org/10.1080/02680513.2011.538563

Petrides, L., Nguyen, L., Kargliani, A., \& Jimes, C. (2008). Open educational resources: Inquiring into author reuse behaviors. In P. Dillenbourg \& M. Specht (Eds.), Times of Convergence. Technologies Across Learning Contexts (pp. 344-353). Springer Berlin Heidelberg. https://doi.org/10.1007/978-3-540-87605-2 39

Pitt, R. (2015). Mainstreaming open textbooks: Educator perspectives on the impact of openstax college open textbooks. The International Review of Research in Open and Distributed Learning, 16(4). http://dx.doi.org/10.19173/irrodl.v16i4.2381

Porter, D. A. (2013). Exploring the practices of educators using open educational resources $(O E R)$ in the British Columbia higher education system [Doctoral Dissertation, Simon Fraser University]. http://summit.sfu.ca/item/13663

Pulker, H., \& Calvi, A. (2013, March). The evaluation and re-use of open educational resources in language teaching - a case study. OER13: Creating a Virtuous Circle, Nottingham, UK. http://oro.open.ac.uk/38056/

Rodgers, E. (2011). Measuring our impact: The Open.Michigan initiative. Celebrating 10 Years of OpenCourseWare. Proceedings of OpenCourseWare Consortium Global 2011, Cambridge, MA. http://hdl.handle.net/2027.42/91308

Ruhleder, K. (2000). The virtual ethnographer: Fieldwork in distributed electronic environments. Field Methods, 12(1), 3-17. https://doi.org/10.1177/1525822X0001200101

Salmons, J. (2010). Online Interviews in Real Time. SAGE Publications Ltd.

Salmons, J. (2011). Designing and conducting research with online interviews. In J. Salmons (Ed.), Cases in Online Interview Research (pp. 1-30). SAGE Publications Ltd.

Stewart, K., \& Williams, M. (2005). Researching online populations: The use of online focus groups for social research. Qualitative Research, 5(4), 395-416. https://doi.org/10.1177/1468794105056916

Tlili, A., Huang, R., Chang, T.-W., Nascimbeni, F., \& Burgos, D. (2019). Open educational resources and practices in China: A systematic literature review. Sustainability, 11(18), 4867. https://doi.org/10/ggzfkg

Tur, G., Urbina, S., \& Moreno, J. (2016). From OER to open education: Perceptions of student teachers after creating digital stories with creative common resources. BRAIN. Broad Research in Artificial Intelligence and Neuroscience, 7(2), 34-40. 
UN General Assembly. (2015). Transforming our world: The 2030 agenda for sustainable development (A/RES/70/1). United Nations. https://sustainabledevelopment.un.org/post2015/transformingourworld

Van Acker, F., Vermeulen, M., Kreijns, K., Lutgerink, J., \& van Buuren, H. (2014). The role of knowledge sharing self-efficacy in sharing open educational resources. Computers in Human Behavior, 39, 136-144. https://doi.org/10.1016/i.chb.2014.07.006

Veletsianos, G. (2015). A case study of scholars' open and sharing practices. Open Praxis, 7(3), 199-209. https://openpraxis.org/articles/abstract/10.5944/openpraxis.7.3.206/

Weller, M. (2012). The openness-creativity cycle in education. Journal of Interactive Media in Education, 2012(1), Art. 2. https://doi.org/10/gg3bw6

Weller, M. (2016). Different aspects of the emerging OER discipline. Revista Educacao e Cultura Contemporanea, 13(31). http://periodicos.estacio.br/index.php/reeduc/article/view/2321

Weller, M., de los Arcos, B., Farrow, R., Pitt, B., \& McAndrew, P. (2015). The impact of OER on teaching and learning practice. Open Praxis, 7(4).

https://openpraxis.org/articles/abstract/10.5944/openpraxis.7.4.227/

Wild, J. (2012). OER engagement study: Promoting OER reuse among academics. SCORE research report. https://ora.ox.ac.uk/objects/uuid:eca4f8cd-edf5-4b38-a9b04dd2d4e59750

Wiley, D. (2016, March 16). "Open" educational resources vs "open” pedagogy: Why meanings matter. Iterating Toward Openness. http://opencontent.org/blog/archives/4496 